\title{
Glyphosate Market in Thailand: Opportunities and Challenges
}

\author{
Adisak Suvittawat \\ Burapha University, International College, Chonburi, Thailand \\ adisaku@buu.ac.th
}

\begin{abstract}
The purpose of this study is to find out the opportunities and challenges of the glyphosate market in Thailand, which is affected by product registration laws, demand, supply, and product positioning and price segmentation. The methodology of this study consists of primary data from 2013 market surveys both at dealer and farmer levels and secondary data collected from 2009-2013 using descriptive methods. The results show that herbicides, fungicides and insecticides werethetop three kinds of imported pesticides used for crop production in Thailand from 2009-2013. Herbicide imports increased fromUS\$291.83 million (MUSD) and 53,615.20 tons in 2009, to 352.93 MUSD and 60,231.52 tons in 2012. Glyphosate was the leading pesticide import in 2012, in cost and amount, at 88.13 MUSD and 19,721 tons. Many glyphosate brands compete in a price-segmented market. Monsanto's Roundup brand is the most expensive, at 18.12-18.75USD per four liters (/4 L). Brands such as Ecomax are priced in the medium range, at13.75-16.25 USD/4 L. This segment has other brands too, such as Market and Popular, and they are sold in different regions. Other brands are in the lowest price range, at 1.25-13.45 USD/4 L. Thailand has not yet approved genetically modified (GM) crops that can tolerate glyphosate, so the market for glyphosate is very limited at the moment. If the Thai government approves GM crops, the glyphosate market will have more opportunity for growth.
\end{abstract}

Keywords: Glyphosate, market, Opportunities, Challenges, Thailand

\section{Introduction}

Thailand is an agricultural country that exports rice, cassava and rubber to the world market (Office of Agricultural Economics, 2011). Pesticides are major ingredients in crop production because they improve yields and reduce labor costs (Poramacom, 2001). Currently, weed problems are solving by using herbicide without damage crops and increasing affordable costs. The using of herbicides in developed countries has been successful and the herbicide penetration rate to many crops such as sugarcane, maize and rice is high (Finney, 1998). Glyphosate is an herbicide that is widely used around the world. Of the top ten active ingredients in the world, it is very interesting that seven are herbicides and of these herbicides, glyphosate is considered the best selling agrochemical (Cobb and Reade, 2010). Since glyphosate is widely used for weed control on both crops and in open areas, the price of glyphosate is sensitive to supply and demand. Glyphosate is also classified as a pesticide that requires product registration before it can be sold. Glyphosate has recently been recommended for use in over 130 countries and the global volume is estimated at about 600 kilotons annually (CCM Information Science and Technology Company, 2008). Since glyphosate is effective at controlling both annual and perennial weed growth, it has become a famous product (Nandula, 2010). Due to glyphosate's unique properties, it was initially utilized to control perennial weeds in ditches and fallow fields. Since it can kill crops, its application on crops is limited. However glyphosate is popular because it can effectively control weeds on both vacant land and in conventional tillage systems, especially before planting. The opportunities and challenges for the glyphosate market depend on many factors such as product registration laws, demand, supply, and product positioning and price segmentation. In Thailand therefore, Thai market conditions must be studied to determine the potential for glyphosate market development.

\section{Methodology}

The analysis is based on primary data from market surveys in 2013 both at the dealer and farmer levels and by applying the descriptive method to secondary data from 2009-2013. This study focuses on the current glyphosate market situation by considering price positioning, and both how and where it is used. Pesticide import statistics were analyzed as well as glyphosate market trends, price trends of key products and competition. 


\section{Results and Discussion}

Glyphosate Market Trends: Agriculture plays an important role in Thailand's economy. Most of Thailand's labor force works in the agricultural sector, producing mainly rice, cassava and rubber for export. The agricultural sector also receives the most capital investment. Table 1 compares the agricultural sector's contribution to Thailand's GDP with non-agricultural sectors in 2011. The sector's impact on GDP was quite low that year due to severe flooding, which ruined crops. In some areas nothing grew for almost 5 months. In 2013, Thailand's shrimp industry suffered from Early Market Syndrome, which had a significant negative impact on the agricultural sector's contribution to GDP. We can see therefore how important agriculture is to the Thai economy, and why many factors that affect agricultural production also affect Thailand's GDP.

Table 1: Percentage of Agricultural Sector Contribution to Thailand's GDPin 2011-2013

\begin{tabular}{llll}
\hline & $\mathbf{2 0 1 1}$ & $\mathbf{2 0 1 2}$ & $\mathbf{2 0 1 3}$ \\
\hline & Q1-Q4 & Q1-Q4 & Q1-Q4 \\
GDP Agriculture & N/A & 3.1 & 1.1 \\
GDPNon-Agriculture & N/A & 6.7 & 3.2 \\
GDP & 1.5 & 6.4 & 2.7 \\
\hline
\end{tabular}

Source: Office of Agricultural Economics, 2011-2013

Table 2: Import values and active ingredients of main pesticide categories from 2009-2012

\begin{tabular}{|c|c|c|c|c|c|c|c|c|c|c|}
\hline Pesticides & 2009 & & 2010 & & 2011 & & 2012 & & 2013* & \\
\hline & $\begin{array}{l}\text { Value } \\
\text { (million } \\
\text { USD) }\end{array}$ & $\begin{array}{l}\text { Active } \\
\text { ingredient } \\
\text { (tons) }\end{array}$ & 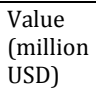 & $\begin{array}{l}\text { Active } \\
\text { ingredient } \\
\text { (tons) }\end{array}$ & $\begin{array}{l}\text { Value } \\
\text { (million } \\
\text { USD) }\end{array}$ & $\begin{array}{l}\text { Active } \\
\text { ingredient } \\
\text { (tons) }\end{array}$ & 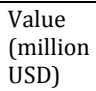 & $\begin{array}{l}\text { Active } \\
\text { ingredient } \\
\text { (tons) }\end{array}$ & $\begin{array}{l}\text { Value } \\
\text { (million } \\
\text { USD) }\end{array}$ & $\begin{array}{l}\text { Active } \\
\text { ingredient } \\
\text { (tons) }\end{array}$ \\
\hline Herbicide & 291.83 & $53,615.20$ & 276.41 & $51,902.14$ & 358.74 & $67,607.73$ & 352.93 & $60,231.52$ & 255.87 & $42,360.30$ \\
\hline Fungicide & 92.75 & $4,890.50$ & 145.93 & $5,972.03$ & 185.56 & $6,980.25$ & 115.19 & $4,420.97$ & 78.95 & $2,828.59$ \\
\hline Insecticide & 124.14 & $8,112.15$ & 120.61 & $9,999.94$ & 121.10 & $10,671.10$ & 121.36 & $4,065.47$ & 70.19 & $3,021.76$ \\
\hline Acaricide & 4.16 & 154.34 & 6.00 & 0.17 & 11.37 & 0.16 & 6.93 & 68.02 & 1.84 & 235.61 \\
\hline Rodenticide & 0.81 & 84.60 & 4.29 & 0.26 & 3.81 & 0.27 & 4.82 & 0.01 & $\mathrm{~N} / \mathrm{A}$ & $\mathrm{N} / \mathrm{A}$ \\
\hline PGR & 5.72 & $1,110.07$ & 1.03 & 0.90 & 1.75 & $1,434.78$ & 1.68 & 501.80 & 2.93 & 204.76 \\
\hline Molluscicide & 1.47 & 94.89 & 0.40 & 82.48 & 4.17 & 75.25 & 2.00 & 201.62 & 0.20 & 24.85 \\
\hline Funigents & 4.61 & 706.99 & 1.33 & 0.58 & 2.37 & 0.41 & 0.0007 & 666.35 & 3.37 & 426.86 \\
\hline
\end{tabular}

*Note: The 2013 information is from January to June

Source: Regulatory Division, Department of Agriculture, Ministry of Agriculture, 2009-2013

Table 3: Top 10 products according to import value and active ingredients in 2012

\begin{tabular}{|c|c|c|}
\hline Common Name & Value (million USD) & Active ingredient (ton) \\
\hline $\begin{array}{ll}\text { glyphosate } & \text { isopropyl } \\
\text { ammonium } & \end{array}$ & 88.13 & 19,721 \\
\hline paraquat dichloride & 75.53 & $10,674.91$ \\
\hline Ametryn & 41.63 & $6,632.06$ \\
\hline difenoconazole & 37.20 & 296.93 \\
\hline propiconazole & 31.29 & 309.85 \\
\hline Atrazine & 22.52 & $4,951.05$ \\
\hline 2,4-D sodium salt & 16.28 & $4,259.60$ \\
\hline 2,4-D dimethyl ammonium & 16.01 & $5,587.63$ \\
\hline abamectin & 14.16 & 75.96 \\
\hline Diuron & 14.08 & $1,932.58$ \\
\hline
\end{tabular}

Source: Regulatory Division, Department of Agriculture, Ministry of Agriculture, 2012

Table 2 shows pesticide imports from January 2009 to June of 2013. It shows the amount and cost of imported pesticides for agricultural production. There was a slight increase from 2009 to 2012,althoughfor the first half of 2013 the value was close to 2009 and 2010 values. Herbicides, fungicides and insecticides were the top three kinds of pesticide imports from 2009-2013, and they were used mainly for crop production. The import values and quantities of herbicides increased from 291.83 MUSD and 53,615.20 tons in 2009 to 352.93 MUSD and 60,231.52 tons in 2012, which means that herbicides can solve the problem of labor shortages in weed management. Insecticide imports from 2009 to 2012 did not change significantly because demand for this pesticide depends mainly on insect infestations. Table 3 shows the top ten kinds of pesticide imports in 2012, with glyphosate at the top of the list with a value of 88.13 MUSD for 19,721 tons. Glyphosate is popular because of its reputation for 
long-lasting weed control and cost effectiveness when compared with paraquat for example, and manual weed management. Glyphosate, paraquat and ametryn are the top three herbicides. Most crop production in Thailand uses new technology to enhance yields and address the problem of labor shortages.

Table 4: Main Crops in Thailand from 2011-2013

\begin{tabular}{|c|c|c|c|c|c|c|c|c|c|c|c|c|}
\hline \multirow[t]{2}{*}{ Crop } & \multicolumn{4}{|c|}{ Planting area (M Hectare) } & \multicolumn{4}{|c|}{ Productivity (M ton) } & \multicolumn{4}{|c|}{ Productivity per hectare (kg.) } \\
\hline & 2011 & 2012 & 2013 & $\%$ & 2011 & 2012 & 2013 & $\%$ & 2011 & 2012 & 2013 & $\%$ \\
\hline $\begin{array}{l}\text { Main } \\
\text { season rice }\end{array}$ & 10.45 & 10.30 & 10.30 & 0.07 & 25.87 & 26.60 & 28.44 & 6.95 & 63 & 66 & 71 & 7.02 \\
\hline $\begin{array}{l}\text { Off season } \\
\text { rice }\end{array}$ & 2.90 & 2.37 & 0.00 & -100 & 12.24 & 9.98 & 0.00 & -100 & 108 & 108 & 0 & -100 \\
\hline Sugarcane & 1.33 & 1.37 & 1.39 & 1.36 & 102.09 & 103.95 & 106.94 & 2.87 & 1,966 & 1,941 & 1,970 & 1.49 \\
\hline Cassava & 1.27 & 1.30 & 1.28 & -1.67 & 26.60 & 27.46 & 28.22 & 2.78 & 538 & 539 & 563 & 4.51 \\
\hline Corn & 1.19 & 1.15 & 1.15 & 0.31 & 5.02 & 4.78 & 4.88 & 2.06 & 108 & 107 & 108 & 1.08 \\
\hline Soybean & 0.05 & 0.04 & 0.03 & -12.5 & 0.08 & 0.06 & 0.05 & -9.13 & 41 & 36 & 37 & 4.00 \\
\hline
\end{tabular}

Source: Office of Agricultural Economics, 2011-2013

Table 4 shows how much land was used to grow Thailand's main crops from 2011-2013. Rice production used the most land in each of the three years, at 10.45, 10.30 and 10.30 million hectares (Mha) respectively. Off-season rice from 2011-2012 required 2.90 and 2.37 Mha. There were water shortages that year, and rice production was low because farmers were encouraged to use less water for crop production. Sugarcane cultivation in 2011, 2012 and 2013used 1.33, 1.37 and 1.39 Mha respectively. The Thai government supports bio-fuel production, which uses sugarcane as a raw material to produce ethanol. This is why the numbers did not change much.

Table 5: Glyphosate segmentation by price

\begin{tabular}{lllll}
\hline Company & Brand Name & $\begin{array}{l}\text { Farmer } \\
\text { Price(USD/4 L) } \\
\text { Q12013 }\end{array}$ & $\begin{array}{l}\text { Farmer } \\
\text { Price(USD/4 L) } \\
\text { Q42013 }\end{array}$ & Segmentation \\
\hline Monsanto & Roundup & 18.12 & 18.75 & Premium \\
Crop Protection & Ecomax & 15 & 16.25 & Medium \\
Pro Chemitech & Market & 15 & 16.25 & Medium \\
Sinochem & Popular & 14.06 & 15 & Medium \\
CropScience & Glyphosate 48 & 13.75 & 15 & Medium \\
Chia Tai & One Up & 13.43 & 13.75 & Medium \\
Wee Thong & Glyphosate 48 & 13.43 & 14.06 & Medium \\
Erawan & Glyphosate 48 & 12.18 & 13.75 & Low \\
Kemer & Glyphosate 48 & 12.18 & 13.75 & Low \\
Sricharoen & Glyphosate 48 & 12.18 & 13.43 & Low \\
Pato & Estate & 11.87 & 13.43 & Low \\
Global Crop & Glyphosate 48 & 11.25 & 13.43 & Low \\
\hline
\end{tabular}

Source: Survey in 2013

Price trends for key products: Table 5 shows the names of the companies that sell glyphosate, product brand names, retail prices in the first and final quarters (Q1 and Q4) of 2013 and price segmentation. Our survey found that glyphosate brand sales depended on sales territories in different regions. The results were related to glyphosate product registrations in Thailand. There were 216 glyphosate products registered and 130 brand names (Thailand Department of Agriculture, 2013). Glyphosate prices in the first quarter of 2013 were lower than in the fourth quarter because the supply of glyphosate from China increased and companies adjusted their prices accordingly. Glyphosate pricing is quite sensitive to demand and supply because glyphosate is the most popular herbicide in the world. When companies do not have enough glyphosate to meet demand, sometimes the price offered to dealers is higher than the selling price. In our survey, price segmentation was divided into three pricing segments. The premium brand was Roundup at 18.12-18.75 USD/4L. The medium price was between 13.75-16.25 USD/4L. In the mid-range were brands such as Ecomax, Market, and Popular, each of which focused on a particular sales region. The lowest price segment was from 11.25-13.45 USD/4L, and these brands also followed a regional sales segmentation. The most popular brand name in the lowest price segment was Glyphosate 48 , not because of brand loyalty but because the low price influenced farmers' purchasing decisions. 
Table 6: Benchmarks for key Glyphosate products

\begin{tabular}{|c|c|c|c|c|c|c|}
\hline Company & $\begin{array}{l}\text { Brand } \\
\text { Name }\end{array}$ & $\begin{array}{l}\text { Brand } \\
\text { Equity }\end{array}$ & $\begin{array}{l}\text { Price } \\
\text { Segmentation }\end{array}$ & $\begin{array}{l}\text { Dealer } \\
\text { profit }\end{array}$ & $\begin{array}{l}\text { Regional } \\
\text { Sales Area }\end{array}$ & $\begin{array}{l}\text { After-sale } \\
\text { Service }\end{array}$ \\
\hline Monsanto & Roundup & High & High & Low & Low & Low \\
\hline $\begin{array}{l}\text { Por } \\
\text { Chemitech }\end{array}$ & Market & Medium & Medium-High & Medium & Medium & Medium \\
\hline Chai Tai & One Up & Medium & Medium & Medium & High & High \\
\hline Sinochem & Popular & Medium & Medium-High & Medium & High & High \\
\hline
\end{tabular}

Source: Survey in 2013

Competition of key products: Table 6 shows the benchmarks for brand equity, price segmentation, dealer profits, sales regions and after-sale service for different companies. The Roundup brand from Monsanto had high brand equity and was positioned at the highest price segment. However, it provided low dealer profits, was sold in fewer places and did not offer much after-sale service. The Market brand from Por Chemitech, had medium brand equity. It was positioned at a mid-range price segment that provided mid-range dealer profits, a medium number of sales territories and more after-sale service than Roundup. Currently dealers need reliable glyphosate companies which depend on brand equity. Some dealers focus only on a low-priced brand for a competitive advantage. High profit margins and good aftersale service are new demands from dealers who understand the need to sustain a competitive edge. Farmers or end-users want to feel brand confidence and want quality products that deliver on their promises. Good quality products and reasonable prices are the factors that farmers are using for their purchasing decisions. Some promotions or incentives, such as giveaways, would encourage farmers to buy products from dealers.

Table 7: Glyphosate sales territories by region and Glyphosate sales by crop in 2013

\begin{tabular}{ll}
\hline Region & Volume (kL) \\
\hline North & 7.56 \\
Northeast & 8.64 \\
Central & 4.05 \\
South & 6.75 \\
Total & 26.75 \\
Crops & Volume (kL) \\
Palm Oil & 5.2 \\
Rubber & 4.7 \\
Rice & 3.4 \\
Fruit crops & 3.0 \\
Sugarcane & 1.7 \\
Cassava & 1.1 \\
Other & 7.65 \\
Total & 26.75 \\
\hline
\end{tabular}

Source: survey in 2013

Table 7 shows glyphosate sales territories by region based on results of a 2013 survey. The biggest glyophosate sales region, according to sales volume, was the Northeast region where 8.64 kL were sold. The second region was the North where $7.56 \mathrm{~kL}$ were sold, followed by the South and Central regions where $6.75 \mathrm{~kL}$ and $4.05 \mathrm{~kL}$ of glyphosate were sold. Since the Northeast region is where the most rice, sugarcane and cassava are produced, glyphosate is used more there. It is the most popular herbicide used to control weeds for those crops. Table 7 shows that in 2013, glyphosate was used most often on plantation crops such as oil palms and rubber trees, at $5.2 \mathrm{~kL}$ and $4.7 \mathrm{~kL}$ respectively. Rice, fruit crops, sugarcane and cassava crops used glyphosate at 3.4, 3.0, 1.7 and $1.1 \mathrm{~kL}$ respectively. Since Thailand has not approved GM crops, glyphosate use is limited to controlling weeds for inter-row cultivation. Glyphosate provides a total of one month's weed control after spraying in rubber and oil palm plantations, which is longer than paraquat, and only annual weeds germinate (Pamplona, 1981). Glyphosate at $2.5 \mathrm{~kg}$ acid equivalents per hectare (ae/ha)can provide $80 \%$ weed control and the percentage increases to $90 \%$ weed control when the glyphosate rate is increased to $3 \mathrm{~kg}$ ae/ha (Sopit, 2012). The results are comparable to tests in the USA (Wolinka, 2003) where glyphosate was applied at $2.5 \mathrm{~kg}$ ae/ha and then provided $90 \%$ weed control. Performance developed further when the glyphosate rate increased to $2.88 \mathrm{~kg}$ ae/ha and was re-applied after $2-3$ months. 


\section{Conclusion}

Thailand's economy still relies on its agricultural sector, which focuses mainly on export crops such as rice, cassava and sugarcane. The weed control systems for these crops are entirely focused on herbicide applications either as pre-emergent herbicides or post-emergent herbicides. Glyphosate is the most popular imported herbicide and is used to control weeds among many crops, both in inter-row cultivation and in open areas. Farmers like it because it is a long-lasting weed control method, and the price is acceptable. Glyphosate market prices are very sensitive to both supply and demand. Price segmentation in Thailand makes glyphosate affordable for farmers. As Thailand has not yet approved glyphosatetolerant GM crops the market for glyphosate is very limited. If the Government approves GM crops, glyphosate will have more opportunities for growth.

\section{References}

CCM Information Science and Technology Company. (2008). Glyphosate Competitiveness Analysis in China. CCM International Limited: Guangzhou, China. Accessed from: http://www.researchandmarkets.com/reportinfo.asp?cat_id=o\&report_id=649031\&q=glyphosat $\mathrm{e} \& \mathrm{p}=1$

Cobb, H. A. \& Reade, P. H. J. (2010). Herbicides and Plant Physiology. Wiley-Blackwell: New York, NY.

Finney, J. R. (1998). World crop protection prospects: demisting the crystal ball. Proceedings of the Brighton Crop Protection Conference-Pests and Diseases: 3-14.

Nandula, V. K. (2010). Glyphosate Resistance in Crops and Weeds: History, Development and Management, John Wiley\& Sons: Hoboken, New Jersey.

Office of Agriculture Economic. 2011. Agricultural Statistics of Thailand Crop Year 2010/2011. Ministry of Agriculture and Cooperative.

Office of Agriculture Economic. 2012. Agricultural Statistics of Thailand Crop Year 2011/2012. Ministry of Agriculture and Cooperative.

Office of Agriculture Economic. 2013. Agricultural Statistics of Thailand Crop Year 2012/2013. Ministry of Agriculture and Cooperative.

Regulatory Division. 2009. Pesticide Statistics. Department of Agriculture, Ministry of Agriculture and Cooperative.

Regulatory Division. 2010. Pesticide Statistics. Department of Agriculture, Ministry of Agriculture and Cooperative.

Regulatory Division. 2011. Pesticide Statistics. Department of Agriculture, Ministry of Agriculture and Cooperative.

Regulatory Division. 2012. Pesticide Statistics. Department of Agriculture, Ministry of Agriculture and Cooperative.

Regulatory Division. 2013. Pesticide Statistics from January-June 2013. Department of Agriculture, Ministry of Agriculture and Cooperative.

Poramacom, N. (2001). Pesticide Markets and Related Situations in Thailand. Kasetsart Journal: Social Sciences, 22, 205-211.

Sopit, J. (2012). Effect of Glyphosate Herbicide Spraying Period on Growth and Yield of Cassava Variety Rayong 11. Thai Agricultural Research Journal, 30(2), 186-191.

Wolinska J. R. (2003). Laboratory and field tests of Roundup 360 SL. Railways Technical and Scientific Center (CNTK):Warsaw, Poland. 